\title{
Effect of Compost Tea or some Botanical Extracts on the Fruit Quality of Pomegranate Trees at Upper Egypt
}

\author{
Kassem M. S. M.
}

\begin{abstract}
This investigation was carried out during 2019 and 2020 seasons on seven-years-old Manfalouty pomegranate (Punica granatum L.) trees grown in a private orchard located at An Nikhaylah, Abu Tij, Assiut Governorate, Egypt to study the effect of compost tea or botanical extracts of licorice root, garlic cloves and moringa leaves foliar spray as natural growth stimulants on manfalouty pomegranate trees. Results revealed that all treatments significantly increased the qualities and quantities of fruit traits. But it is preferred, under Upper Egypt conditions to Spray $10 \%$ compost tea or $1.5 \%$ moringa extracts for improving fruit weight, chemical characteristics and productivity whilst spraying $0.5 \%$ licorice root extract is preferred to obtain the highest fruit size, in addition to garlic cloves extract $(1 \%)$ which is preferred for reducing the fruit acidity $\%$.
\end{abstract}

Key words: Pomegranate, Compost tea, Moringa extract. Garlic extract, Licorice extrac,

\section{INTRODUCTION}

Pomegranate (Punica granatum L.) is one of the ancient and highly praised favorite fruit of Mediterranean, tropical and subtropical regions of the world. In modern terminology, compost tea (compost extract) produced from the fermented compost in water (Litterick et al., 2004) has been utilized in agriculture as a good source of organic matter and soil amendment that provide plants with mineral nutrients (Abbasi et al., 2002). Moreover, it is very rich in growth regulators and phytohormones which stimulates the microorganisms that have a beneficial effect on plant, improves soil physical and chemical properties and suppress some plant diseases pathogen (Biocycle, 2004). However, Bayoumi and Hafez (2006) stated that compost tea significantly increased all growth parameters, chlorophyll content, yield and its quality as compared with recommended dose of nitrogen. Recent studies pointed out to the possibility of using some plant extracts such as licorice root and moringa leaves extracts to enhance growth and yield of plants (Aldroush, 1976 and Nasira et al., 2016). Licorice root contains many of chemical compounds such as gleserezin, glycyrrhejel and licorice acid and vlavonideh. Licorice extract had stimulating effect similar to that of growth regulators on vegetative and flowering characteristics (Alajaili, 2005). Moreover,
Moses et al. (2002) added that it contained a wide range of elements and nutrients. Recta and Bhatnager (2011) also confirmed that licorice extract can decrease transpiration rate, maintaining cell fullness and reducing water loss due to transpiration. This behavior is because the licorice extract contains sugars and gum substances that increase the percentage of total soluble solids in plant cells and water retaining due to presence of iron and magnesium. Abou-Hussein et al. (2000) stated that licorice increases the effectiveness of cellulose enzyme which is important in the lateral expansion of cells results in accelerating the plant growth. In addition, Hussein (2008) found that spraying date palm with licorice extract at $5 \mathrm{~g} / \mathrm{L}$. enhanced the fruit quality. Sheren and Eman (2015) found that spraying pear with licorice extracts gave the highest values of fruit quality parameters. Likewise, garlic (Allium sativum) cloves extract contains enzymes and more than 200 chemical compounds, some of its volatiles are more important i.e. allicin that gives garlic its antibiotic properties. Its higher contents of volatile and sulphur compounds put both in the top due to their real and essential roles they play in fruiting process of various fruit trees (Bruneton, 2001). Garlic also contains vitamins, minerals, flavonoids, ascorbic acid, sulphur and trace of iodine. Abd El-Hamied and El-Amary (2015) and El-Sharony et al. (2015) reported that garlic extract showed comparatively greater efficacy on nutrition and hormonal status of pear and mango respectively. Likewise, foliar spraying of moringa leaf extract increased the strength of growth, ability to resistant to adverse environmental conditions, delaying fruit aging, improves quality and quantity of yield (Nasira et al., 2016). In addition, Moringa oleifera contains seven times more vitamin $\mathrm{C}$ than orange, ten times vitamin $\mathrm{A}$ than carrot, seventeen times $\mathrm{Ca}$ than milk, fifteenth times $\mathrm{K}$ than bananas, twenty five times Fe than spinach and nine times proteins than yogurt (Fuglie, 2000). Also, plants contain amino acids, fatty acids, phenolics and its leaves contain high zeatin and cytokinin (Barciszweski, et al., 2000 and Farooq et al., 2007). Thus, the aim of this study was to evaluate the effect of spraying by compost tea, Moringa leaf, garlic cloves and licorice roots extracts on some of the qualitative and quantitative characteristics of the fruits of pomegranate yield cv. Manfalouty. 


\section{MATERIALS AND METHODS}

This study was carried out during 2019 and 2020 growing seasons on seven-year-old Manfalouty Pomegranate (Punica granatum L.) trees grown in a private orchard located at An Nikhaylah, Abu Tij, Assiut Governorate, Egypt. All experimental trees were selected for their uniformity in growth, size, vigor and fruiting habits which planted at $5 \times 5$ meters apart. Also, all trees received the ordinary management practices usually applied in the pomegranate orchard, including irrigation, pest control, hoeing and fertilization. Treatments were the spraying with compost tea and botanical extracts of licorice root, garlic cloves and moringa leaves as natural growth stimulants. The experiment was arranged in a randomized complete block design with four replicates as follows:

- Control: spraying with distilled water as a control treatment,

- $10 \%$ compost tea extract

- $0.5 \%$ licorice root extract

- $1 \%$ garlic cloves extract

- $1.5 \%$ Moringa leaves extract

The experiment conditions were:

1. All treatments were applied at the rate of one litter per tree

2. The extracts were applied in three dates: the first spraying was before flowering on late week of April, with two months interval (last week of April, June and August).

3. All common agricultural practices for pomegranate tree were applied according to the recommendation of the Egyptian Ministry of Agriculture and Land Reclamation.

4. Some constituent's analysis of soil, compost tea, licorice roots, garlic cloves and moringa leaves are shown in Tables 1a, 1b, 1c, 1d and 1e, respectively. However, the physical and chemical analysis of the experimental soil was carried out according to Page et al. (1982).

Preparing the extracts was carried out prior the begging of each spraying time. The procedure of preparing the extracts can be described as follows:

\section{Compost tea extract (C-tea):}

Compost tea extract (Table 1b) was prepared by the method described by Al-Fartusy (2003) by dissolving a certain weight of the compost in distilled water (weight/volume) and left in plastic containers for 24 hours, then shaked well and put through a $0.64 \mathrm{~cm}$ sieve to remove any unnecessary large fragments.

\section{Licorice Roots Extract (L. Extr.):}

The aqueous extract (Table 1c) of licorice roots (Glycyrrhiza glabra) was prepared by boiling 5 g D.M in one liter of distilled water for 15 minutes. The solution filtered using a cotton cloth, and re-filtered through Whatman filter paper No. 12 and completed by distilled water to one liter.

\section{Garlic extract (Gar. Ext.):}

The $1 \%$ garlic aqueous extract (Table 1d) was prepared by blending $10 \mathrm{~g}$ of fresh mature cloves in one liter of distilled water, frozen and thawed two times, and then filtered and diluted by distilled water to one liter (El-Desouky et al., 1998).

\section{Moringa extract}

Leaves powder of Moringa oleifera (Table 1e) was obtained from the unit of moringa production at National Research Center, Giza, Egypt and different concentrations of aqueous extracts were prepared by blending $15 \mathrm{~g}$ leaves powder in one liter water and left for one hour. The obtained suspension homogenized and filtered using a cotton cloth. Finally, the solution re-filtered using Whatman filter paper No. 2 and rose to one liter (Hossain et al., 2012).

Table 1a. Some physical and chemical properties of the experimental soil

\begin{tabular}{cccccccccccc}
\hline \multirow{2}{*}{$\begin{array}{c}\text { Soil } \\
\text { Texture }\end{array}$} & $\begin{array}{c}\mathbf{E C} \\
\mathbf{d S} / \mathbf{m}\end{array}$ & $\mathbf{p H}$ & $\begin{array}{c}\mathbf{P} \\
\mathbf{\%}\end{array}$ & $\begin{array}{c}\mathbf{N a}^{+} \\
\mathbf{\%}\end{array}$ & $\begin{array}{c}\mathbf{K}^{+} \\
\mathbf{\%}\end{array}$ & $\begin{array}{c}\mathbf{C a}^{++} \\
(\mathbf{m e q} / \mathbf{L})\end{array}$ & $\begin{array}{c}\mathbf{M g}^{++} \\
(\mathbf{m e q} / \mathbf{L})\end{array}$ & $\mathbf{C O}_{3}$ & $\begin{array}{c}\mathbf{H C O}^{-} \\
(\mathbf{m e q} / \mathbf{L})\end{array}$ & $\mathbf{S O}^{-{ }^{--}}$ & $\mathbf{C l}^{-}$ \\
\hline Clayey & 1.21 & 8.1 & 0.63 & 3.98 & 0.61 & 23.08 & 7.54 & - & 3.14 & 15.92 & 22.992 \\
\hline
\end{tabular}

Table 1b. The physicochemical properties of organic compost of tea (Sheren et al., 2017)

\begin{tabular}{ccccccccc}
\hline $\mathbf{E C}(\mathbf{d} \mathbf{S} / \mathbf{m})$ & $\mathbf{P h}$ & $\mathbf{N ~ p p m}$ & $\mathbf{P}$ ppm & K ppm & Ca ppm & Mg ppm & Fe ppm & Zn ppm \\
\hline $\mathbf{0 . 8 1 2}$ & 6.55 & 251 & 7.5 & 212 & 85 & 119 & 64 & 7.1 \\
\hline
\end{tabular}


Table 1c. Extracted components of licorice root extract (Sheren et al., 2017)

\begin{tabular}{cccccc}
\hline $\begin{array}{c}\text { Reducing } \\
\text { Sugar }(\boldsymbol{\%})\end{array}$ & $\begin{array}{c}\text { Non- } \\
\text { reducing } \\
\text { sugar }(\boldsymbol{\%})\end{array}$ & Starch $(\boldsymbol{\%})$ & Glycyrrhizic acid $(\boldsymbol{\%})$ & $\begin{array}{c}\text { Humidity } \\
(\boldsymbol{\%})\end{array}$ & GA3 (\%) \\
\hline 3.23 & 10.27 & 4.76 & 26 & 5.88 & 0.63 \\
$\mathrm{P}(\mathrm{mg} / \mathrm{g})$ & $\mathrm{K}(\mathrm{mg} / \mathrm{g})$ & $\mathrm{Ca}(\mathrm{mg} / \mathrm{g})$ & $\mathrm{Mg}(\mathrm{mg} / \mathrm{g})$ & $\mathrm{Fe}(\mathrm{mg} / \mathrm{g})$ & $\mathrm{Zn}(\mathrm{mg} / \mathrm{g})$ \\
540 & 1235 & $\begin{array}{c}560 \\
\text { Antioxidants } \mathrm{mg} / 100 \mathrm{~g} \text { dry weight basis }\end{array}$ & 33 & 3.6 \\
\hline $\begin{array}{c}\text { Total } \\
\text { phenols }\end{array}$ & $\begin{array}{c}\text { Total } \\
\text { flavonoids }\end{array}$ & Saponins & Carotenoids & Vitamin C & Tannins \\
\hline 405.02 & 114.91 & 27.99 & 11.78 & 1.2 & 47.54 \\
\hline
\end{tabular}

Table 1d. Extracted components of garlic cloves according to El-Merghany et al. (2019)

\begin{tabular}{cccccc}
\hline $\begin{array}{c}\text { GA3 } \\
(\mathbf{m g} / \mathbf{1 0 0 g} \\
\text { F.W) }\end{array}$ & Ca $(\%)$ & Mn (ppm) & S04 (\%) & Mg (\%) & Zn (ppm) \\
\hline 1.633 & 1.363 & 94.4 & 0.181 & 1.23 & 66.5 \\
\hline
\end{tabular}

Table 1e. Chemical extracted components of moringa leaves (Moyo et al., 2011)

\begin{tabular}{|c|c|c|c|c|c|}
\hline Components & $\mathbf{C a}$ & $\mathbf{P}$ & $\mathbf{K}$ & $\mathbf{M g}$ & S\% \\
\hline Value & $3.65 \%$ & $0.3 \%$ & $1.5 \%$ & $0.5 \%$ & $0.63 \%$ \\
\hline Components & $\mathrm{Zn}$ & Mn & Fe & Se & $\mathbf{C u}$ \\
\hline Value & $13.03 \mathrm{mg} / \mathrm{kg}$ & $86.8 \mathrm{mg} / \mathrm{kg}$ & $490 \mathrm{mg} / \mathrm{kg}$ & $363 \mathrm{mg} / \mathrm{kg}$ & $8.25 \%$ \\
\hline Components & $\begin{array}{c}\text { Crude } \\
\text { protein \% }\end{array}$ & $\begin{array}{c}\text { No of amino } \\
\text { acids }\end{array}$ & $\beta$-Carotene & Vitamin-E & $\begin{array}{c}\text { Total } \\
\text { polyphenols }\end{array}$ \\
\hline Value & $30.3 \%$ & 19 & $18.5 \mathrm{mg} / 100 \mathrm{~g}$ & $77 \mathrm{mg} / 100 \mathrm{~g}$ & $2.02 \%$ \\
\hline
\end{tabular}

\section{Recorded data (M. Ext.):}

Fruits of each treatment were harvested in the first of October of both seasons, to determine the yield/tree. Ten fruits were randomly taken from each replicate to study both physical and chemical fruit properties. The average fruit length $(\mathrm{cm})$, width $(\mathrm{cm})$ and weight $(\mathrm{g})$, pulp (\%), juice (\%), yield $(\mathrm{kg} / \mathrm{tree})$ and fruit cracking percentage were calculated. Chemical characteristics such as total soluble solids (TSS), reducing sugars, vitamin $\mathrm{C}$ content (ascorbic acid/100 ml juice) and acidity (\%), were determined following the methods by A.O.A.C (2000). Total anthocyanin content of juice was determined according to Rabino and Mancinelli (1986). Hydrolysable tannin content of juice was estimated according to Cam and Hisil (2010). To determine leaf mineral content $(\mathrm{N}, \mathrm{P}, \mathrm{K}, \mathrm{Ca}$ and $\mathrm{Mg}$ ), leaf samples were taken at the end of experiment. Each sample was collected randomly at a constant height and at all directions of the tree. Total NPK were colorimetrically determined as described by Cottenie et al. (1982).

\section{Statistical analysis:}

The obtained data were statistically analyzed according to Gomez and Gomez (1984) using LSD test at $5 \%$ level for distinguishing the significant differences between various treatment means.

\section{RESULTS AND DISCUSSION}

\section{Fruit length, fruit width and fruit weight}

Table 2 and Fig.1 showed that each length, width and weight of fruit were significantly affected by compost tea, licorice, garlic and moringa extracts treatments in both seasons. However, licorice extract gave the highest fruit length $(9.375$ and $9.075 \mathrm{~cm})$ and width $(10.275$ and $9.475 \mathrm{~cm})$ in the first and the second seasons, respectively. This increase may be due to the effect of licorice extract which contain many various important compounds such as Triterpene saponins (including glycyrrhizin), mevalonic acid which is the initiator in the synthesis of gibberellins in plants, polysaccharides, vitamins, and many minerals which play an important role in the growth of plant (Shibata 2000 and Zadeh et al.2013). Furthermore, compost tea spraying produced the highest fruit weight in both seasons with no significant differences between compost tea and moringa extract treatments in the $1^{\text {st }}$ 
Table 2. Length, width and weight of Manfalouty fruit as affected by treatment by compost tea or some botanical extracts during 2019 and 2020 growing seasons

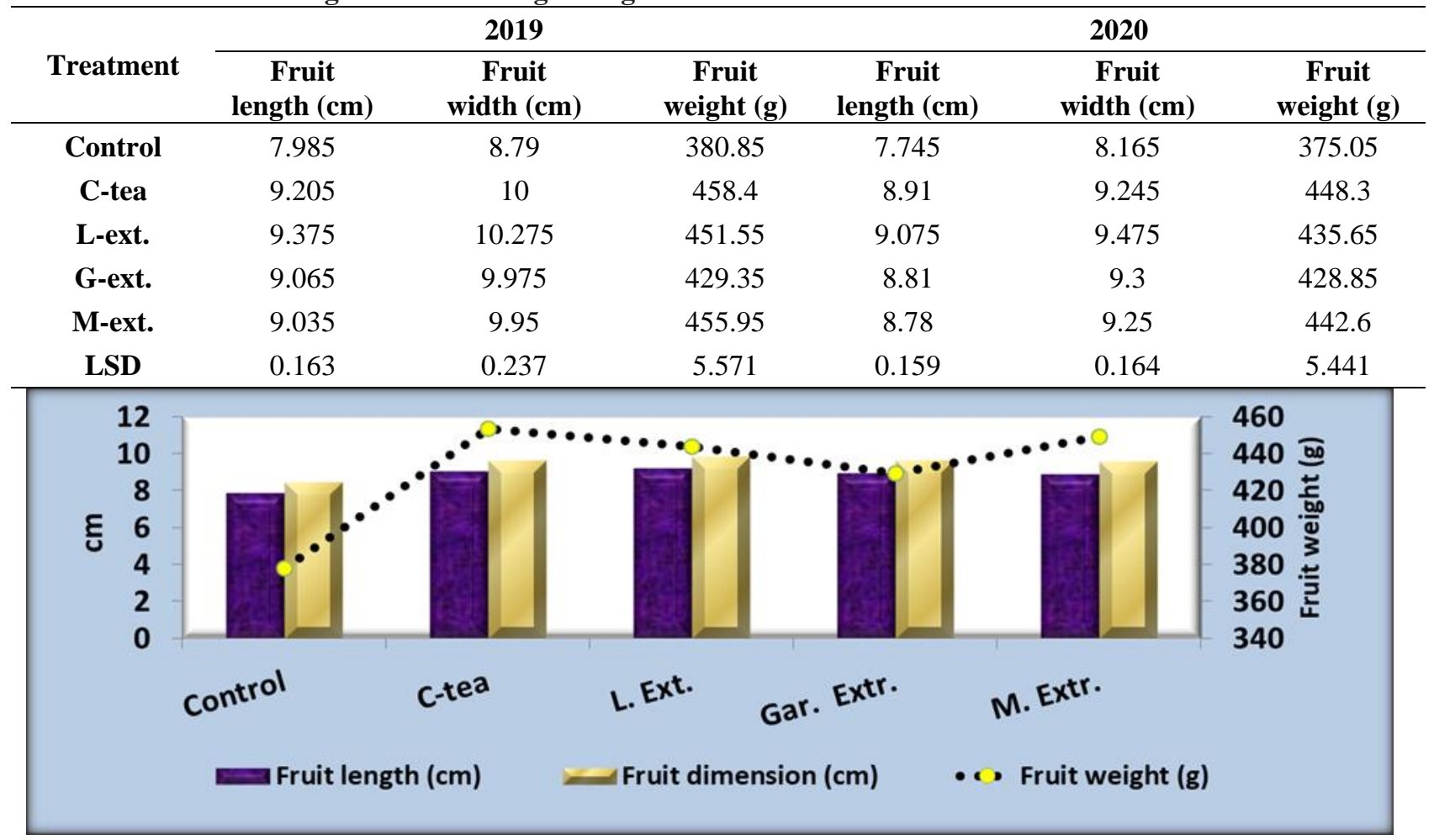

Fig.1. Length, width and weight of Manfalouty fruit as affected by compost tea and some botanical extracts (average of both seasons)

season. In addition, the control recorded the lowest fruit length, fruit width and fruit weight in both seasons.

Table 3 and Fig. 2 showed that anthocyanin, pulp \% and yield $\mathrm{kg} /$ tree were significantly affected by compost tea, licorice, garlic and moringa extracts treatments in both seasons. Both $1.5 \%$ moringa leaves and $1 \%$ garlic extracts treatments recorded the highest values of anthocyanin (63.55 and 64.89 $\mathrm{mg} / 100 \mathrm{~g})$ and $(61.76$ and $65.51 \mathrm{mg} / 100 \mathrm{~g})$ with no significant differences between them against the control treatment $(55.21$ and $57.05 \mathrm{mg} / 100 \mathrm{~g})$ in 2019 and 2020 seasons, respectively. Using natural extracts such as moringa and garlic helps in availability of minerals and may be capable for producing growth regulating like auxins, cytokinins, GA or vitamins and the earlier reports indicated that plant growth hormone in small amounts modified a given physiological process and rarely acted alone as the action of two or more are necessary to produce a physiological effect
(Hafez et al., 2013, Mona, 2001 and Vagner et al., 2003). Furthermore, compost tea recorded the highest pulp percentage and yield/tree at both seasons and $2^{\text {nd }}$ one, respectively with no significant differences were obtained between compost tea and moringa extract for pulp \% ( $1^{\text {st }}$ season) and yield/tree (both seasons). Accordingly, compost tea proved to be the most efficient in enhancing tree fruiting of Manfalouty trees hence it increased fruit weight, fruit pulp percentage and improved tree yield (yield $\mathrm{Kg} /$ tree). Such findings could be explained on the basis of the beneficial effect of compost tea as it contains enough values of macro, micronutrients and has high useful amount of needed bacteria, fungi and actinomycetes. The present results are in agreement with those of Abdou (2010) working on "Le-Conte" pear, Shaaban, et al. (2011) on "Anna" apple and Aly (2012) on "Costata" persimmon who studied different fertilization methods. 
Table 3. Anthocyanin (mg/100g), pulp (\%) and yield $\mathrm{kg} /$ tree of Manfalouty as affected by compost tea and some botanical extracts during 2019 and 2020

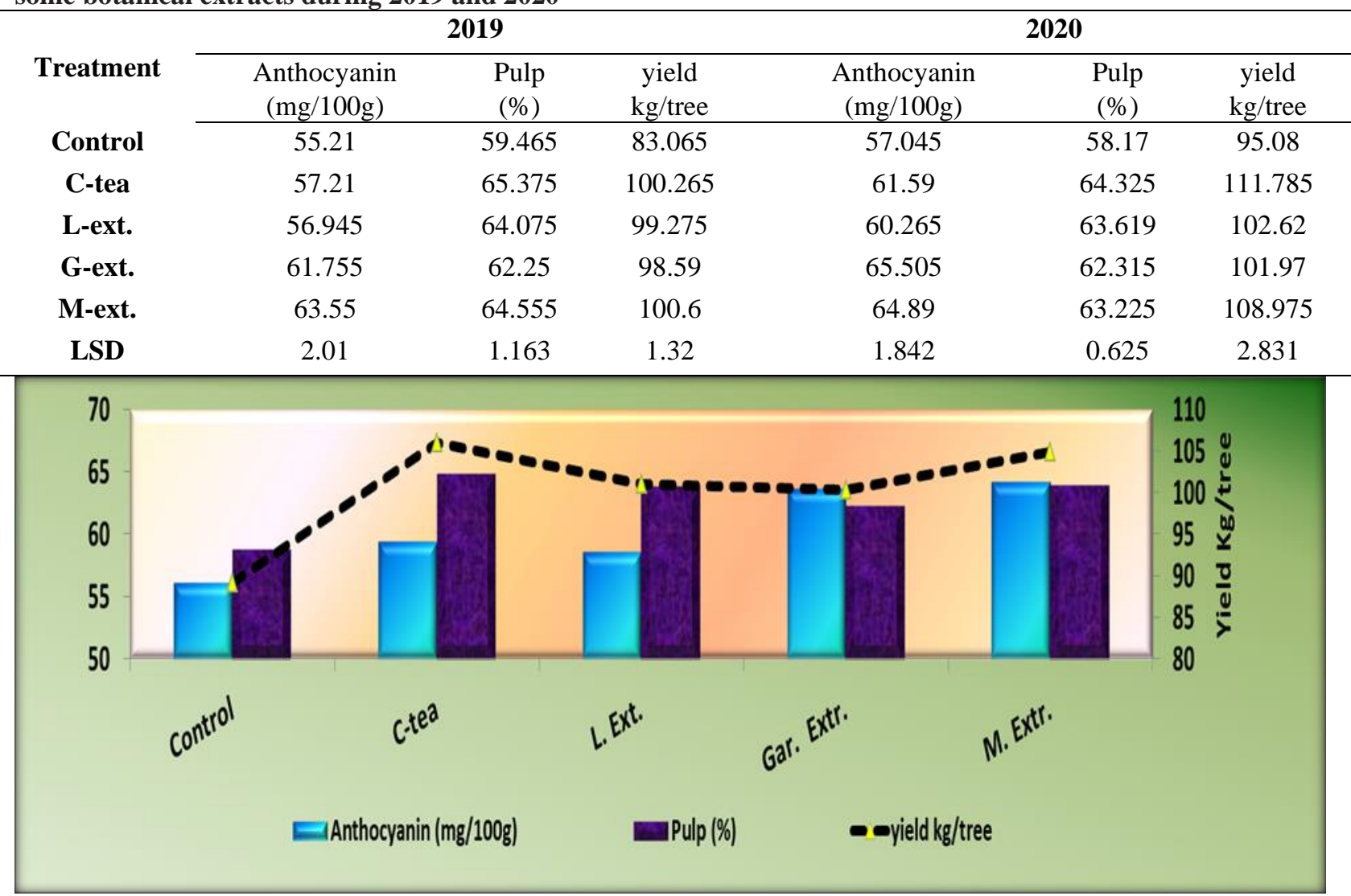

Fig 2. Anthocyanin (mg/100g), Pulp (\%) and yield kg/tree of Manfalouty as affected by compost tea or some botanical extracts (average of both seasons)

\section{Fruit cracking, acidity and tannins content:}

Table 4 illustrates that compost tea, licorice extract, garlic extract and moringa extract treatments significantly reduced each of fruit cracking (\%), acidity (\%) and tannins content $(\mathrm{mg} / 100 \mathrm{ml})$ of Manfalouty pomegranate trees as compared with the control in the first and second

seasons. In this respect, $10 \%$ compost tea and $1 \%$ garlic extract treatments recorded the lowest values of fruit cracking (6.45 and $7.35 \%)$ and (6.2 and $6.5 \%$ ) against (13.8 and $13.95 \%)$ for the control treatment in 2019 and 2020 seasons, respectively. As for acidity and tannins contents, garlic cloves and moringa leaves extracts exhibited the lowest values $(0.975 \%$ and $2.27 \mathrm{mg} / 100 \mathrm{ml}$, respectively) as average of both seasons (Fig. 3). Findings could be explained on the basis of the beneficial effect of compost tea due to it contains enough values of macro, micronutrients and has high useful amount of needed bacteria and fungi and, on the other hand, the enhancement of fruit quality with decreasing of acidity and tannins percentages could be due to the effective components of garlic and moringa extract (i.e., some growth regulators, antioxidants, protein, amino acid nutritive, minerals and phytohormone) (Arystanova et al., 2001).

Vitamin-C, juice \%, total soluble solids and reducing sugars content

Table 5 showed that vitamin-C, juice \%, total soluble solids and reducing sugars content were significantly affected by all treatments in both seasons. Tabulated data illustrate that Moringa followed by compost tea treatments induced a high positive effect on fruit ascorbic acid (Vitamin-C) content, with no significant differences between them, as compared with the control treatment. Moreover, average of both seasons (Fig. 4) revealed that $1.5 \%$ moringa leaves extract treatment gave the highest values of fruit ascorbic acid content $(27.735 \mathrm{mg} / \mathrm{ml})$ as compared with the control $(23.753 \mathrm{mg} / 100 \mathrm{ml})$ treatment. Likewise, moringa followed by compost tea treatments induced a significant positive effect on juice, total soluble solids 
and reducing sugars in the first, second seasons (Table 5) as well as average of both seasons (Fig. 4), with nonsignificant differences between them. On the other side, control gave the lowest four contents in both seasons. The enhancement effect of moringa and compost tea may be due to their essential roles in signal transduction system, membrane stability and functions, activating transporter enzymes, metabolism and translocation of carbohydrates (Bhaskaran et al., 1985 and Smirnoff, 1996).

Table 4. Fruit cracking (\%), Acidity (\%) and Tannins content $(\mathrm{mg} / 100 \mathrm{ml})$ of Manfalouty as affected by compost tea and some botanical extracts during 2019 and 2020

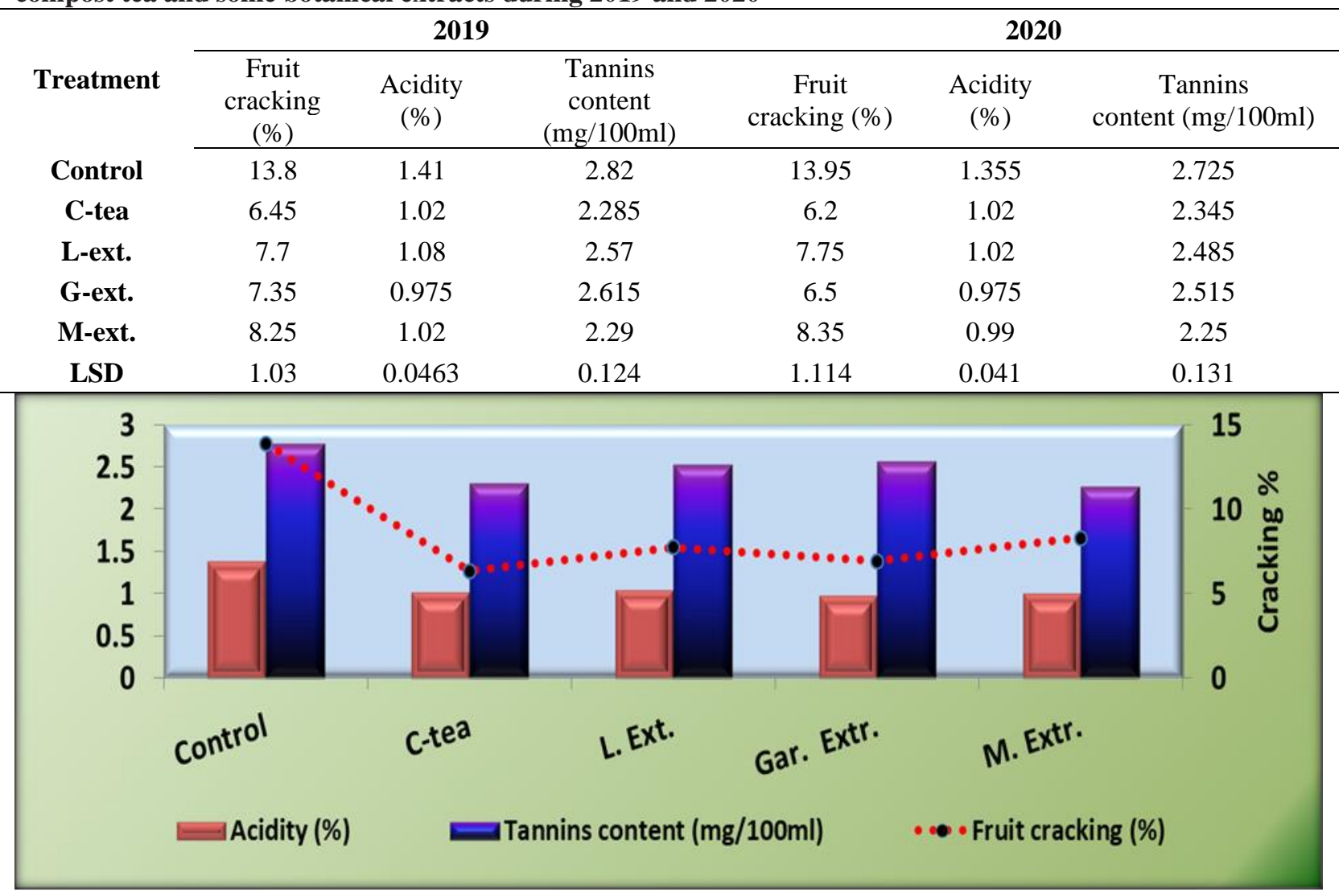

Fig. 3 Fruit cracking (\%), Acidity (\%) and Tannins content $(\mathrm{mg} / 100 \mathrm{ml})$ of Manfalouty as affected by compost tea or some botanical extracts (average of both seasons)

Table 5. Ascorbic acid, juice \%, TSS\% and reducing sugars content of Manfalouty fruit as affected by compost tea or some botanical extracts during 2019 and 2020

\begin{tabular}{ccccccccc}
\hline & \multicolumn{3}{c}{$\mathbf{2 0 1 9}$} & \multicolumn{3}{c}{$\mathbf{2 0 2 0}$} \\
\cline { 2 - 9 } Treatments & $\begin{array}{c}\text { V.C } \\
(\mathbf{m g} / \mathbf{1}\end{array}$ & $\begin{array}{c}\text { Juice } \\
\mathbf{0 0}\end{array}$ & $\begin{array}{c}\text { TSS } \\
\mathbf{( \% )}\end{array}$ & $\begin{array}{c}\text { Reducing } \\
\text { sugars } \\
\mathbf{( \% )}\end{array}$ & $\begin{array}{c}\text { V.C } \\
(\mathbf{m g} / \mathbf{1 0 0} \\
\mathbf{m l})\end{array}$ & $\begin{array}{c}\text { Juice } \\
(\boldsymbol{\%})\end{array}$ & $\begin{array}{c}\text { TSS } \\
(\boldsymbol{\%})\end{array}$ & $\begin{array}{c}\text { Reducing } \\
\text { sugars } \\
(\boldsymbol{\%})\end{array}$ \\
\hline Control & 23.5 & 41.9 & 15.46 & 10.94 & 23.97 & 40.85 & 14.95 & 10.99 \\
C-tea & 27.1 & 48.92 & 16.35 & 12.49 & 27.17 & 49.58 & 16.24 & 12.39 \\
L-ext. & 27.1 & 46.81 & 15.72 & 11.27 & 27.11 & 47.85 & 15.34 & 11.29 \\
G-ext. & 27.0 & 49.3 & 15.8 & 11.33 & 26.85 & 48.92 & 15.73 & 11.24 \\
M-ext. & 27.7 & 49.36 & 16.43 & 12.58 & 27.74 & 49.51 & 16.39 & 12.72 \\
LSD & 0.62 & 1.86 & 0.60 & 1.11 & 0.60 & 1.86 & 0.64 & 1.13 \\
\hline
\end{tabular}




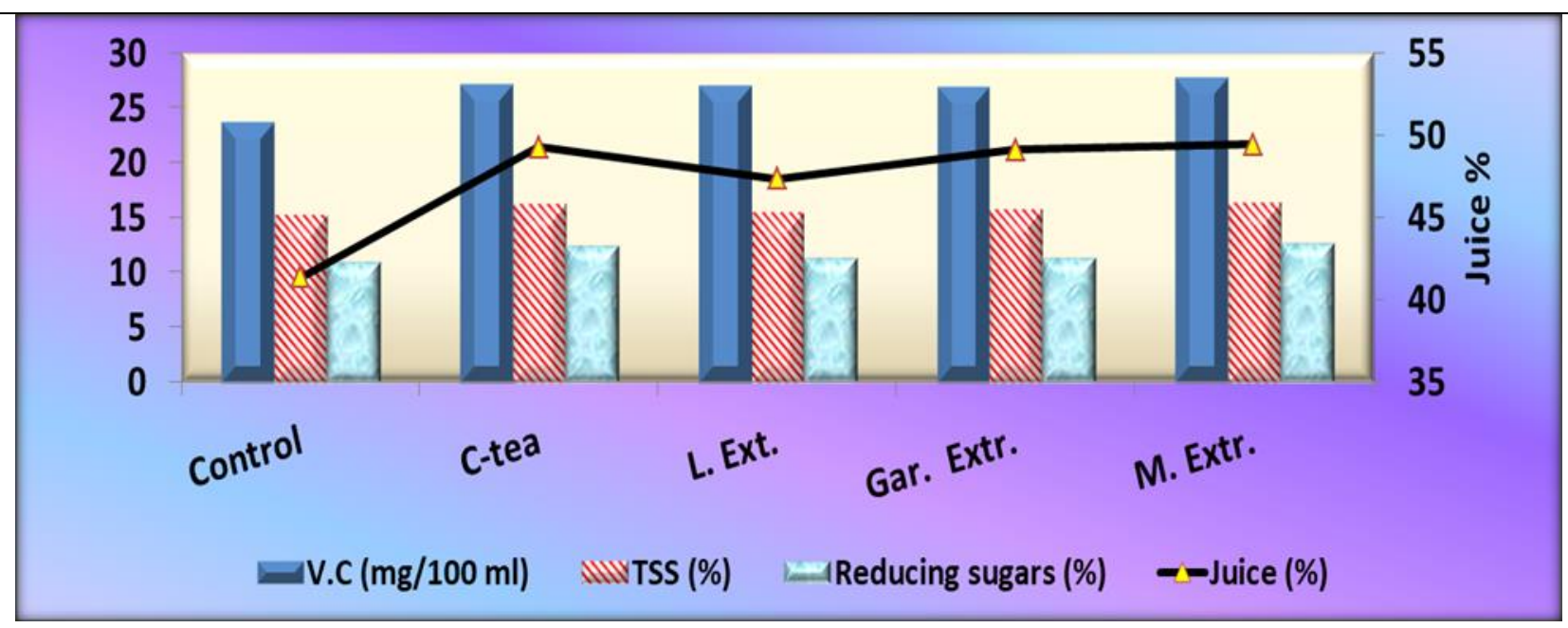

Fig. 4. Ascorbic acid (V.C), juice \%, TSS\% and reducing sugars content of Manfalouty fruit as affected by compost tea and or some botanical extracts average of both seasons

\section{Leaf mineral contents:}

Table 6 and Fig. 5 showed that foliar applications of all treatments significantly increased $\mathrm{N}, \mathrm{P}, \mathrm{K}, \mathrm{Mg}$ and $\mathrm{Ca}$ of leaf as compared to the control treatment. However, compost tea exhibited the highest effect on $\mathrm{N}$, $\mathrm{P}, \mathrm{Mg}$ and $\mathrm{Ca}$ in both and average of both seasons as well as $\mathrm{K}$ content in $2^{\text {nd }}$ season and average seasons. No significant differences between licorice roots and garlic cloves extracts on $\mathrm{N}, \mathrm{P}, \mathrm{Mg}$ and $\mathrm{Ca}$ in both seasons. Generally, the effect on average of both seasons showed that compost tea exhibited the highest positive effect on all leaf mineral contents, i.e., $\mathrm{N}, \mathrm{P}, \mathrm{K}, \mathrm{Mg}$ and $\mathrm{Ca}$.

Table 6. Leaf mineral contents of Manfalouty cv. as affected by compost tea and some botanical extracts during 2019 and 2020

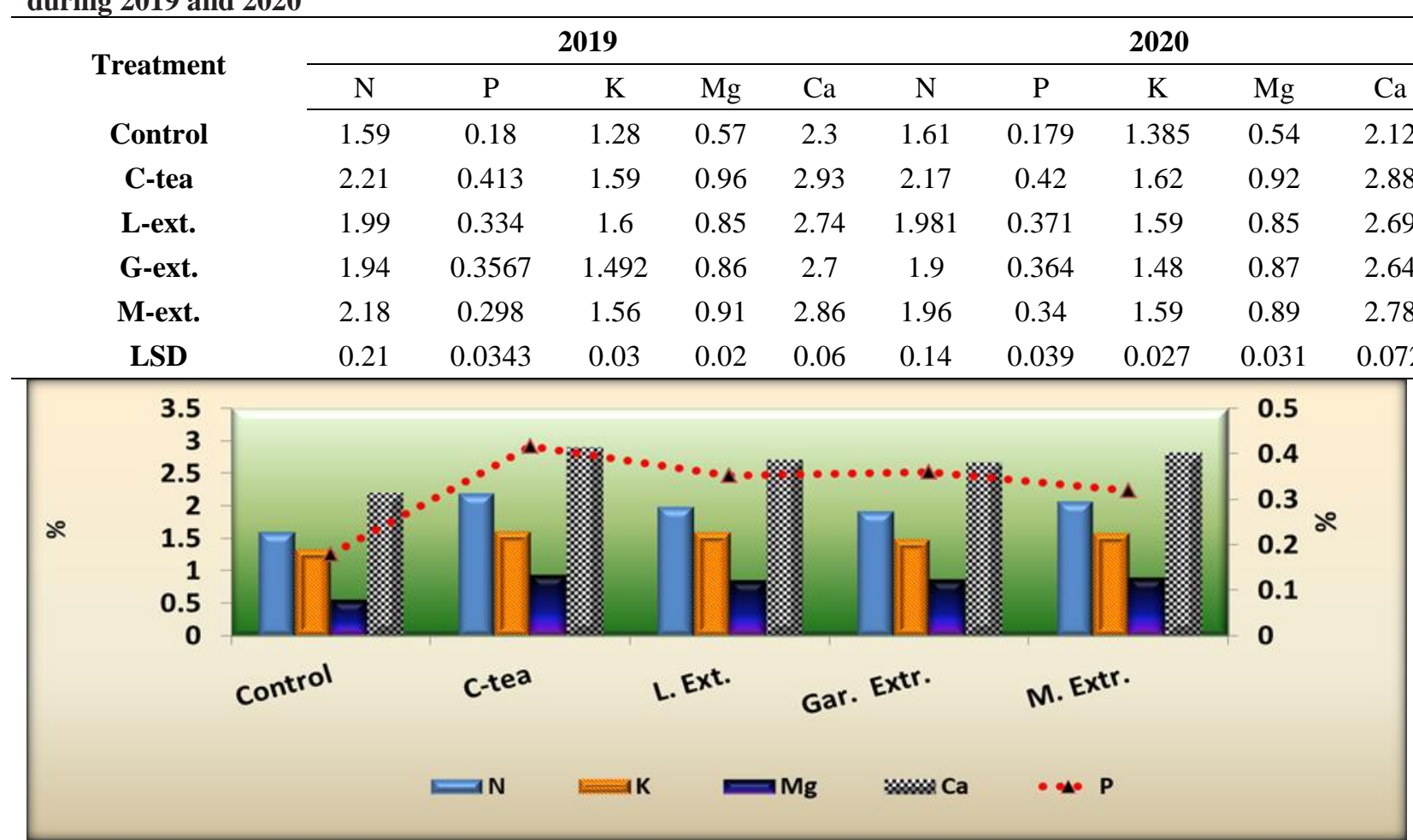

Fig. 5. Leaf Mineral Contents of Manfalouty cv. as affected by compost tea or some botanical extracts (average of both seasons) 
By studying different extracts treatments, the present results are in harmony with the findings of Abdou (2010) on "Le-Conte" pear, Shaaban, et al. (2011) on "Anna" apple and Aly (2012) on "Costata" persimmon. Several researches stated that foliar feeding is more efficient than soil fertilization; the result is totally true in case of micronutrients under arid and semi-arid conditions (Amberger, 1991 and El-Sayed et al., 2000 and Fayek, et al., 2014).

Concerning the compost tea, Fayed (2010) reported the enhancement of physical and chemical traits of pomegranate, following aerial applications on trees based on the increased assumption of microelements by foliar feeding. Here, our results revealed that compost tea foliar spraying increased acceptance of Manfalouty, suggesting that compost-based formulates could contribute to improve the quality by enhancing fruit attributes. It is possible to hypothesize the involvement of compost-based treatments in stimulation of secondary metabolites biosynthesis. Accordingly, Siddiqui et al. (2011) found that compost tea treatments caused an increase in the concentration of terpenoid-related compounds in the aromatic medicinal herb, Centella asiatica.

\section{CONCLUSION}

The obtained results revealed that compost tea exhibited the highest fruit weight, pulp \%, yield/tree, $\mathrm{N}$, $\mathrm{P}, \mathrm{K}, \mathrm{Mg}$ and $\mathrm{Ca} \%$ as well as the reductive Fruit cracking percentage, whilst the moringa extract exhibited the highest anthocyanin, Vitamin-C, juice \%, TSS and reducing sugars as well as the reductive tannins content. In meantime, licorice extract exhibited the highest fruit length and width while garlic extract exhibited the highest reductive acidity $\%$. It could be concluded that spraying Manfalouty pomegranate trees with compost tea at $10 \%$ or $1.5 \%$ moringa leaves extract was necessary to get high yield, reduce the fruit cracking percentage, acidity and tannins as well as improve fruit quality and could be recommended due to their environmentally friendly treatment, high potentiality as well as the nutritive value.

\section{REFERENCES}

Abbasi, P.A., J. Al-Dahmani, F. Sahin, H.A.J. Hoitink and S.A. Miller. 2002. Effect of compost amendments on disease severity and yield of tomato in conventional and organic production systems. Plant Dis., 86: 156-161

Abd El-Hamied, S.A. and E.I. El-Amary. 2015.Improving growth and productivity of "pear" trees using some natural plants extracts under north Sinai conditions. J. Agri. and Vet. Sci., 8 (1):1-9

Abdou, N.A. 2010.Response of "Le-Conte" pear trees to organic and some biofertilizers in comparison with chemical fertilizer. M.Sc. Thesis, Fac. Agric. Cairo Univ.
Abou-Hussein, M.R., S.F. Mostafa and A.W. Yousef. 2000. Effect of garlic bulb on flowering, sex ratio and pumpkin productivity. Adjust the sex ratio by applying a different portion of bulb garlic extract. Egypt. J. Hort. 2: 11-22

Al-Ajeeli, T. A. Z. 2005. Effect GA3 and some nutrients to produce glycyrrhizgin and some other components in the plant licorice (Glycyrrhiza glabra L.) Ph.D. dissertation, Faculty of Agriculture, University of Baghdad, Iraq, P 93.

Al-Droush, A. K. 1976. Studying the effect of the location and date of the gene on the key components of the raw material and the dry extract of licorice in Iraq. Master Thesis, Faculty of Agriculture / University of Baghdad. Iraq.

Al-Fartusy; B. A. J. 2003. Effect of aqueous extracts of some organic in the growth of wheat Triticum aestirum L. Master Thesis - Department of Soil and Water Science, Faculty of Agriculture, University of Baghdad, Iraq.

Aly, D. R. D.2012. Physiological studies on persimmon "Diospyros kaki" trees. Ph.D. Thesis, Fac. Agric. Banha Univ.

Amberger, A. A. 1991. Importance of micronutrients for crop production under semi-arid conditions of North Africa and Middle East. In Proceeding the $4^{\text {th }}$ Micronutrients Workshop. Amman, Jordan., pp: 5-30.

A.O.A.C. Association of Official Agricultural Chemists. 2000. Official Methods of Analysis, $12^{\text {th }}$ Ed. Benjamin Franklin Station, Washington D.C. U.S.A. : 490-510.

Arystanova, T., M. Irismetov and A. Sophekova. 2001. Chromatographic determination of glycyrrhizinic acid in Glycyrrhizaglabra preparation. Chem. Nat. Com., 37:8991.

Barciszweski, J., G. Siboska, S. I. Rattan and B. F. Clark. 2000. Occurrence, biosynthesis and properties of kinetin (N6-furfuryladenine). Plant Growth Reg., 32: 257-265.

Bayoumi Y. A. and Y. M. Hafez. (2006). Effect of organic fertilizers combined with benzo $(1,2,3)$ thiadiazole-7carbothioic acid S-methyl ester (BTH) on the cucumber powdery mildew and the yield production. Acta Biologica Szegediensis, 50(3-4):131-136.

Bhaskaran, S., R. H. Smith and R. J. Newton. 1985. Physiological change in cultured sorghum cells in response to induced water stress. I. Free praline. Plant Physiol., 79: 266-269.

Biocycle. 2004. Bulding a knowledge base for compost tea. J. Composting and Organic Recycling, June:1-2

Bruneton, J. 2001. Farmacogenosia. Zaragoza (ed.) Acriba.: 294-296.

Cam, M. and Y. Hisil.2010. 'Pressurized water extraction of polyphenols from pomegranate peels' Food Chem., 123 (3): 878-885.

Cottenie, A., M. Verloo, G. Velghe and R. Comerlynk. 1982. Chemical analysis of plant and soil. Ghent, Belgium, Laboratory of Analytical and Agro-chemistry State University. 
El-Desouky, S. A., A. L. A. Wanas and Z. M. A. Khedr . 1998. Utilization of some natural plant extracts (of garlic \& yeast) as seed-soaked materials to squash (Cucurbitapepo L.). 1- Effect on growth, sex expression and fruit yield \& quality. Annals Agric. Sci. Moshtohor, 36(2): 839-854

El-Merghany S., M. I. El-Desouky, and S. A. Abd ElHamied. 2019. Improving Productivity and Fruit Quality of Ferehy Date Palm Cultivar under Siwa Oasis Conditions. Egypt. J. Hort., 46 (2): 179-193.

El-Sayed, M. A., A. A. Mervant and A. H. Ali. 2000.Response of Flame seedless grapevine to application of ascorbic acid. The $2^{\text {nd }}$ conf. Agric. Sci. Assuit, Egypt, pp: 317340.

El-Sharony T. F, S. F. El-Gioushy and O. A. Amin. 2015. Effect of foliar application with algae and plant extracts on growth, yield and fruit quality of fruitful mango trees cv. Fagri Kalan. Journal of Horticulture. 2(4):1-6.

Farooq, A., L. Sajid, A. Muhammad and H.G. Anwarul. 2007. Moringa oleifera: a food plant with multiple medicinal uses. Phytotherapy Res., 21: 1725.

Fayed, T. A. 2010. Effect of Compost Tea and Some Antioxidant Applications on Leaf Chemical Constituents, Yield and Fruit Quality of Pomegranate. World J. Agric. Sci., 6: 402-411

Fayek M.A., T.A. Fayed, E. M. El-Fakhrani and Sh. N. Sayed. 2014. Yield and fruit quality of "le-conte" pear trees as affected by compost tea and some antioxidants applications. J. Hortic. Sci. Ornament. Plants, 6 (1): 01 08.

Fuglie, L. J., (2000). The Miracle Tree: Moringa oleifera: Natural Nutrition for the Tropics. The multiple Attributes of Moringa, pp: 172.

Gomez, K. A. and A. A. Gomez . 1984. Statistical Procedures for Agricultural Research. 2 nd ed., John Wiely and Sons, New York.

Hafez, O. M., M. A. Saleh and S. R. El-Lethy. 2013. Response of some seedlings olive cultivars to foliar spray of yeast and garlic extracts with or without vascular arbuscular mycorrhizal fungi. World Appl. Sci. J., 24(9): 1119-1129.

Hossain, M. M., G. Miah, T. Ahamed and N. S. Sarmin . 2012. Study on allelopathic effect of Moringa oleifera on the growth and productivity of mungbean. International J. Agric. Crop Sci., 4(15): 1122-1128.

Hussein, J. S. 2008. Effect of bagging and spraying licorice extract in the early maturity and improve the qualities of the fruit of the date palm Phoenix dactylifera L. cultivars Sayer and Mahallawy. M.Sc. Thesis, Faculty of Agriculture - University of Baghdad.

Kamel H. M. 2015. Response of manfalouty pomegranate transplants to foliar spray and soil drench applications with some natural extracts. Journal of Horticultural Sci. Ornament. Plants 7 (3): 107-116.
Litterick, A. M., L. Harrier, P. Wallace, C. A. Waston and M. Wood. 2004. The role of uncomposted materials, compost, manures and compost extracts in reducing pests and diseases incidence and severity in sustainable temperate agricultural and horticultural crop production. Plant Sci., 23(6): 453-479.

Mona, G. S. 2001. Response of banana and guava plants to some biological mineral fertilizers. M.Sc. Thesis, Fac. Agric. Alex. Univ., Egypt.

Moses, T. N., W. A. Abdul-Jabbar and A. N. Elwy .2002. A study of some local licorice root powder components (Glycyrrihiza glabra L.). The Iraqi J. Agric. Sci., 33(4): 30-38.

Moyo B., P. J. Masika, A. Hugo and V. Muchenje . 2011. Nutritional characterization of Moringa (Moringa oleifera Lam.) leaves. Afric. J. Biotech., 10(60): 1292512933.

Nasira, M., A. S. Khan, S. M. A. Basra and A. U. Malik.2016. Foliar application of moringa leaf extract, potassium and zinc influence yield and fruit quality of 'Kinnow' mandarin. Scientia Horticulturae, 210: 227-235.

Page, A. L., Miller R. H. and D. R. Keeney. 1982. Methods of soil analysis. No. (9), Part 2. Chemical and microbiological properties. Am. Soc., Agron., Inc. Soil. Sci., Mad., Wisc., U.S.A.

Rabino, I. and A. L. Mancinelli. 1986. 'Light, temperature and anthocyanin production'. J. Plant Physiol., 81 (3): 922-924.

Recta, K. A. and A. K. Bhatnager. 2011. Effect of aqueous extract of Sargassum johnstonii Setchell and Gardner on growth, yield and quality of Lycopersicon esculentum Mill. Journal of Applied Phycology, 23: 623-633.

Shaaban, M. S., A. M. K. Abd El-Aal and F. F. Ahmed. 2011.Insight into the effect of salicylic acid on apple trees growing under sandy saline soil. Res. J. Agric. Biol. Sci., 7(2): 150-156.

Sheren, A. A. H. and I. A. Eman . 2015.Improving growth and productivity of "pear" trees using some natural plants extracts under North Sinai conditions. IOSR J. Agric. Veterinary Sci., 8 (1): 01-09.

Shibata, S. 2000. A drug over the millennia pharmacognosy, chemistry and pharmacology of licorice. J. of the Pharmaceutical Society of Japan, 120: 849-862.

Siddiqui, Y., T. M. Islam, Y. Naidu and S. Meon. 2011. The conjunctive use of compost tea and inorganic fertilizer on the growth, yield and terpenoid content of Centella asiatica (L.) Urban. Sci. Hort., 130:289-295.

Smirnoff, N. 1996. The function and metabolism of ascorbic acid in plants. Ann. Bot., 78: 661-669.

Vagner, M. L., A. R. Ciro and D. R. Joao. 2003.Plant physiology and biochemistry giberrellic and cytokinins effects on soybean growth. Scientia Agricola., 60(3).

Zadeh, J. B., Z. M. Kor and M. K. Goftar. 2013. Licoric (Glycyrrihiza glabra L.) as a valuable medicinal plant. Inter. J. Advanced Biolog. Biomed. Res., 1(10): 1281-1288.

Zuhair A. D. 2010. Effect of foliar spray of zinc and liquorice root extract on some vegetative and flowering growth parameters of two strawberry varieties (Fragaria $\mathrm{x}$ ananassa Duch.) Mesopotamia J. Agric., 38: 152-151. 


\section{الملخص العربي \\ تأثير شاى الكمبوست وبعض المستخلصات النباتية على أثجار الرمان فى الصعيد

$$
\text { مصطفى صابر محمود قاسم }
$$

كبير من جودة ومحصول الثمار ولكن يفضل تحت ظروف

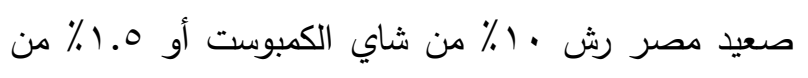

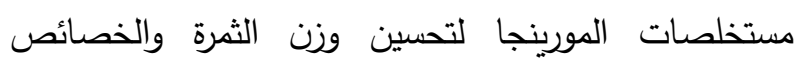
الكيميائية والإنتاجية بينما رش هـ ـ ـ من مستخلص جذور

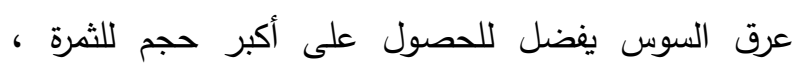
بالإضافة إلى مستخلص فصوص الثوم ( \%) مفضل لتقليل حموضة الثرة.

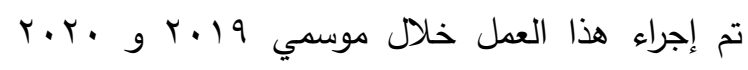
على أشجار رمان صنف منفلوطي عمرها سبع سنوات في مزرعة خاصة بقرية النخيلة، أبو تيج، محافظة أسيوط لدراسة تأثير الرش الورقى (ثلاث مرات) باستخدام شاي الكمبوست

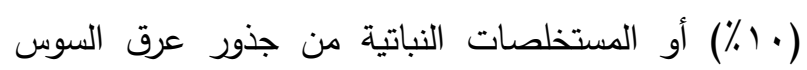
(0.0\%) اوفصوص الثوم (1\%) اوأوراق المورينجا (0. (1\%)

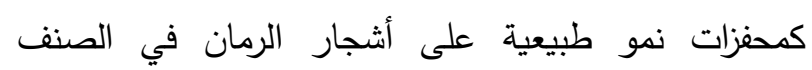
منفلوطي. أظهرت النتائج أن جميع المعاملات تزيد بشكل فئل 